\title{
Disclosure Status and Associated Factors Among Children on Antiretroviral Therapy in Ethiopia
}

\author{
Walelign Atomsa Tucho' \\ Aderajew Nigusse

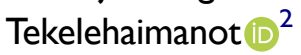 \\ Mahilet Berhanu Habte (iD) ${ }^{2}$ \\ 'Department of Disease Prevention and \\ Control, Bench Sheko Zone Health \\ Office, Mizan-Aman, Southwest Ethiopia; \\ ${ }^{2}$ Department of Population and Family \\ Health, Faculty of Public Health, Jimma \\ University, Jimma, Ethiopia
}

Background: The World Health Organization recommends that children should be informed of their HIV status at age 6-12 years. However, disclosure of HIV status among children is very low in resource-limited areas, particularly in Ethiopia. So, the aim of this study was to determine the prevalence of disclosure and associated factors among a cohort of HIVinfected children in southwest Ethiopia.

Methods: A facility-based cross-sectional study design was employed among caregivers of HIV-positive children aged 6-15 in Bench sheko and West Omo zone Southwest Ethiopia, from March 1 to April 20, 2020. Study participants were included using a consecutive sampling technique. Data were collected using a pretested interviewer administered questionnaire and checklist. A multivariable logistic regressions model was used to identify independent predictors of disclosure. The significance of association was declared by AOR at $95 \%$ confidence and a $p$-value $<0.05$.

Results: A total of 327 participants were involved in the study yielding a $95 \%$ response rate. The prevalence of HIV-positive status disclosure was 45.6\% (95\% CI=41.01-51.02). Caregiver secondary education and above $(\mathrm{AOR}=3.16,95 \% \mathrm{CI}=1.07-9.34)$, caregiver discussed about disclosure with health professionals $(\mathrm{AOR}=9.56,95 \% \mathrm{CI}=4.88-18.74)$, child age 10-15 year old $(\mathrm{AOR}=3.64,95 \% \mathrm{CI}=1.64-8.08)$, duration on $\mathrm{ART}>5$ years $(\mathrm{AOR}=5.08$, $95 \% \mathrm{CI}=1.57-16.37)$, treatment follow-up at hospital $(\mathrm{AOR}=2.23,95 \% \mathrm{CI}=1.27-5.01)$ and having treatment support for Children $(\mathrm{AOR}=3.84,95 \% \mathrm{CI}=1.88-7.85)$ were independent predictors of HIV-positive status disclosure.

Conclusion: Disclosure of HIV status to children is low. Caregivers educational status, caregivers discussion with health professional, older child, duration on ART of more than 5 year, getting treatment service from hospital, and having a treatment support group are factors that enable disclosure. Therefore, concerted efforts based on the findings of this study will be required to improve the disclosure status among HIV-positive children.

Keywords: disclosure, antiretroviral therapy, child

\section{Introduction}

HIV has a devastating impact on both adults and children. Globally the number of people living with HIV was 38 million, of these 1.8 million were children $(<15$ years old) in 2019. Most $(90 \%)$ of them were from sub-Saharan Africa. ${ }^{1}$ In Ethiopia, nearly 710,000 people were living with HIV; of these 59,000 were children less than 15 years old. However, only 38\% of them were on antiretroviral therapy (ART). ${ }^{2}$

Disclosure has been defined as a state in which a child has knowledge about his/ her HIV status. ${ }^{3}$ While there is convincing evidence on the benefits of
Correspondence: Mahilet Berhanu Habte Tel +25I-9122464I3

Email mahitesfa.mt@gmail.com 
Table I Sociodemographic Characteristics of Caregivers of Bench Sheko and West Omo Zone, Southwest Ethiopia 2020 $(n=327)$

\begin{tabular}{|c|c|c|c|}
\hline Variable & Category & Frequency & $\begin{array}{l}\text { Percentage } \\
\text { (\%) }\end{array}$ \\
\hline \multirow{3}{*}{$\begin{array}{l}\text { Age of the } \\
\text { respondent (years) }\end{array}$} & $19-30$ & 64 & 19.6 \\
\hline & $31-40$ & 191 & 58.4 \\
\hline & $>40$ & 72 & 22.0 \\
\hline \multirow[t]{2}{*}{ Sex } & Male & 93 & 28.4 \\
\hline & Female & 234 & 71.6 \\
\hline \multirow[t]{4}{*}{ Religion } & Muslim & 72 & 22.0 \\
\hline & Orthodox & 148 & 45.3 \\
\hline & Protestant & 98 & 30.0 \\
\hline & Others* & 9 & 2.7 \\
\hline \multirow[t]{4}{*}{ Marital status } & Single & 14 & 4.3 \\
\hline & Married & 224 & 68.5 \\
\hline & Divorced & 45 & 13.8 \\
\hline & Widowed & 44 & 13.5 \\
\hline \multirow[t]{5}{*}{ Occupation } & $\begin{array}{l}\text { Government } \\
\text { employed }\end{array}$ & 86 & 26.3 \\
\hline & Farmer & 50 & 15.3 \\
\hline & Merchant & 65 & 19.9 \\
\hline & Daily laborer & 75 & 22.9 \\
\hline & Unemployed & 51 & 15.6 \\
\hline \multirow[t]{3}{*}{ Income } & $\leq 500$ & 33 & 10.1 \\
\hline & $501-1,000$ & 68 & 20.8 \\
\hline & $>1,000$ & 226 & 69.1 \\
\hline \multirow[t]{3}{*}{ Educational status } & $\begin{array}{l}\text { No formal } \\
\text { education }\end{array}$ & 39 & 11.9 \\
\hline & $\begin{array}{l}\text { Primary level } \\
(I-8)\end{array}$ & 148 & 45.3 \\
\hline & $\begin{array}{l}\text { Secondary } \\
\text { and above }\end{array}$ & 140 & 42.8 \\
\hline \multirow[t]{2}{*}{ Residence } & Urban & 163 & 49.2 \\
\hline & Rural & 164 & 50.8 \\
\hline \multirow[t]{2}{*}{ Family size } & $\leq 3$ & 198 & 60.6 \\
\hline & $>3$ & 129 & 39.4 \\
\hline
\end{tabular}

(Continued)
Table I (Continued).

\begin{tabular}{|l|l|l|l|}
\hline Variable & Category & Frequency & $\begin{array}{l}\text { Percentage } \\
\text { (\%) }\end{array}$ \\
\hline $\begin{array}{l}\text { Caregivers relation } \\
\text { to the child }\end{array}$ & $\begin{array}{l}\text { Biological } \\
\text { family }\end{array}$ & 281 & 85.9 \\
\cline { 2 - 4 } & $\begin{array}{l}\text { Non- } \\
\text { biological } \\
\text { family }\end{array}$ & 46 & 14.1 \\
\hline
\end{tabular}

Note: *Catholic, wakefeta

developmentally appropriate pediatric HIV disclosure, the prevalence report is low because of different factors. It is challenging for healthcare providers, families, and caregivers as they face challenges on the decision when and how to disclose. Informing children of their HIVpositive status is important in the long-term management of HIV infection. ${ }^{4}$ However, the rate of disclosure to infected children varies widely throughout the world. In developed countries such as in the United States, a prospective study conducted among above 5 years old children shows that HIV diagnosis disclosure was reported up to $100 \%{ }^{5}$ In contrast, in resource-limited settings documented findings revealed very low levels of disclosure. ${ }^{6-8}$ Findings from low and middle income countries revealed that the level of HIV status disclosure ranges from $0-69 \%{ }^{5}$ In sub-Sahara Africa, $67.3 \%$ of caregivers did not disclose to the child about their HIV status. ${ }^{7}$

The World health organization (WHO) in 2011 released guidelines on HIV status disclosure for children should be from 6-12 years old. ${ }^{4}$ The African Network for the Care of Children Affected by HIV/AIDS (ANECCA) also recommends that pediatric HIV disclosure should start as early as 5-7 years old. ${ }^{9}$ Similarly, Ethiopian national HIV/AIDS treatment guidelines recommend the process of disclosure should begin as early as 4-6 years of age and it should be done over time. ${ }^{10}$ However, in Ethiopia, studies indicated that children who know their HIV-positive status range from $28.5-49.4 \% .{ }^{11-14}$ Literature shows that disclosure of HIV status helps children to seek social support, free from the situation of accidental disclosure, and may decrease disruptive behaviors. Additionally, it would help to improve medication adherence, coping skills, and practice safer sex to prevent secondary transmission. The benefitis not limited 
Table 2 Socio Demographic Characteristics of HIV-Positive Children of Bench Sheko and West Omo Zone, Southwest Ethiopia $2020(n=327)$

\begin{tabular}{|c|c|c|c|}
\hline Variables & Category & Frequency & $\begin{array}{l}\text { Percentage } \\
\text { (\%) }\end{array}$ \\
\hline \multirow[t]{2}{*}{ Age of the child } & 6-9 years & 119 & 36.4 \\
\hline & $10-15$ years & 208 & 63.6 \\
\hline \multirow[t]{2}{*}{ Sex of the child } & Male & 131 & 40.1 \\
\hline & Female & 196 & 59.9 \\
\hline \multirow{2}{*}{$\begin{array}{l}\text { Age at which ART } \\
\text { was initiated }\end{array}$} & $<5$ years & 240 & 73.4 \\
\hline & $\begin{array}{l}5 \text { years and } \\
\text { above }\end{array}$ & 87 & 26.6 \\
\hline \multirow[t]{2}{*}{$\begin{array}{l}\text { Place of ART follow- } \\
\text { up }\end{array}$} & $\begin{array}{l}\text { Health } \\
\text { center }\end{array}$ & 197 & 60.2 \\
\hline & Hospital & 130 & 39.8 \\
\hline \multirow[t]{2}{*}{ Duration on ART } & $<5$ years & 68 & 20.8 \\
\hline & $\begin{array}{l}5 \text { years and } \\
\text { above }\end{array}$ & 259 & 79.2 \\
\hline \multirow{4}{*}{$\begin{array}{l}\text { Schooling status of } \\
\text { the child }\end{array}$} & Not started & 32 & 9.8 \\
\hline & Kindergarten & 43 & 13.1 \\
\hline & $\begin{array}{l}\text { Primary }(1- \\
8)\end{array}$ & 233 & 71.3 \\
\hline & $\begin{array}{l}\text { Secondary } \\
9-12)\end{array}$ & 19 & 5.8 \\
\hline \multirow{2}{*}{$\begin{array}{l}\text { Presence of social } \\
\text { support for the child }\end{array}$} & Yes & 109 & 33.3 \\
\hline & No & 218 & 66.7 \\
\hline \multirow{2}{*}{$\begin{array}{l}\text { Child lost his/her } \\
\text { family by HIVIAIDS }\end{array}$} & Yes & 78 & 23.9 \\
\hline & No & 249 & 76.1 \\
\hline \multirow[t]{2}{*}{ History of admission } & Yes & 93 & 28.4 \\
\hline & No & 234 & 71.6 \\
\hline \multirow{2}{*}{$\begin{array}{l}\text { History of } \\
\text { opportunistic } \\
\text { infection }\end{array}$} & Yes & 193 & 59 \\
\hline & No & 134 & 41 \\
\hline \multirow{4}{*}{$\begin{array}{l}\text { Base line WHO } \\
\text { clinical staging }\end{array}$} & Stage I & 55 & 16.8 \\
\hline & Stage II & 156 & 47.7 \\
\hline & Stage III & 107 & 32.7 \\
\hline & Stage IV & 9 & 2.8 \\
\hline
\end{tabular}

Abbreviations: WHO, World Health Organization; ART, antiretroviral therapy. to the child but also for caregivers by relieving the stress and anxiety that accompanies secrecy and deception, creating the opportunity to develop a trusting relationship and more open communication with the child. ${ }^{15-17}$

Studies conducted in Bale, North Gondar, and East Gojjam in Ethiopia show the prevalence of HIV disclosure to be $28.5 \%, 39.5 \%$, and $33.3 \%$, respectively. However, this study was not done in Bench sheko and West Omo zone Southwest Ethiopia. This area is a cash crop area and people are commonly engaged in traditional gold mining work. A study done in this area among gold mining workers shows that HIV preventive behavior of the mining workers was low. ${ }^{18}$ Therefore, this study intends to examine the magnitude and determinants of HIV disclosure status among children in Bench sheko and West Omo zone, Southwest Ethiopia. The study will help for evidence-based interventions and will fill the research gap in the study area as well for local evidence.

\section{Methods and Materials Study Area, Design, and Period}

A facility-based cross-sectional study design was employed from March 1-April 20, 2020 in Bench sheko and West Omo zone, south west Ethiopia. The area is located $585 \mathrm{~km}$ from Addis Ababa, which is the center of Ethiopia. In Bench sheko and West Omo zone there are three public hospitals and 41 health centers. Among these facilities only three hospitals and 10 health centers are currently providing ART services. The total ART users in the study area were 4,148. Among those, 427 were children under 15 years old.

\section{Population, Sample Size, and Sampling Methods}

The study population included caregivers of HIV-positive children aged 6-15 years, on ART for at least 6 months and clinical monitoring charts of children. Sample size was determined taking the prevalence of HIV status disclosure among children from a study conducted in Bale, ${ }^{14}$ which was $28.5 \%$ and considering assumptions: alpha of $5 \%$ and $10 \%$ nonresponse rate. Then the final sample size became 344 caregivers of HIV-positive children aged 6-15 with their respective records. The calculated sample size was distributed proportionally to size for each health facility. Study participants were included using a consecutive sampling technique. Finally, all participants provided written informed consent prior to enrollment into the study. 
Table 3 Independent Predictors of HIV-Positive Status Disclosure to Infected Children in Bench Sheko and West Omo Zone Public Health Facilities, Southwest Ethiopia, $2020(n=327)$

\begin{tabular}{|c|c|c|c|c|c|c|}
\hline \multirow[t]{2}{*}{ Variable } & \multirow{2}{*}{$\begin{array}{l}\text { Response } \\
\text { Categories }\end{array}$} & \multicolumn{2}{|c|}{ Disclosure Status } & \multirow[t]{2}{*}{ OR $(95 \% C)$} & \multirow{2}{*}{$\begin{array}{l}\text { AOR }(95 \% \\
\text { Cl) }\end{array}$} & \multirow[t]{2}{*}{ p-value } \\
\hline & & $\begin{array}{l}\text { Disclosed } \\
(n, \%)\end{array}$ & $\begin{array}{l}\text { Not Disclosed } \\
(\mathbf{n}, \%)\end{array}$ & & & \\
\hline \multirow[t]{3}{*}{ Educational status of the careivers } & $\begin{array}{l}\text { No formal } \\
\text { education }\end{array}$ & $10(6.7)$ & $29(16.2)$ & 1 & 1 & I \\
\hline & Primary (I-8) & $72(48)$ & $76(42.7)$ & $\begin{array}{l}2.75(1.26- \\
6.04)\end{array}$ & $\begin{array}{l}1.78(0.59- \\
5.37)\end{array}$ & 0.170 \\
\hline & $\begin{array}{l}\text { Secondary and } \\
\text { above }\end{array}$ & $67(45.3)$ & $73(41.1)$ & $\begin{array}{l}2.66(1.21- \\
5.87)\end{array}$ & $\begin{array}{l}3.16(1.07- \\
9.34)\end{array}$ & $0.037^{*}$ \\
\hline \multirow[t]{2}{*}{$\begin{array}{l}\text { Caregivers discussion with health professionals } \\
\text { about disclosure }\end{array}$} & Yes & $123(83)$ & $47(26.4)$ & $\begin{array}{l}13.19(7.7- \\
22.56)\end{array}$ & $\begin{array}{l}9.56(4.88- \\
18.74)\end{array}$ & $0.00 I^{*}$ \\
\hline & No & $26(17)$ & $|3|(73.6)$ & 1 & 1 & 1 \\
\hline \multirow[t]{2}{*}{ Age of the child } & $10-15$ years & $134(90)$ & $74(41.6)$ & $\begin{array}{l}12.56(6.81- \\
23.14)\end{array}$ & $\begin{array}{l}3.64(1.64- \\
8.08)\end{array}$ & $0.00 I^{*}$ \\
\hline & $6-9$ years & $15(10)$ & $104(58.4)$ & 1 & 1 & 1 \\
\hline \multirow[t]{2}{*}{ Duration on ART } & $>5$ years & $143(96)$ & $116(65.2)$ & $\begin{array}{l}12.74(5.32- \\
30.49)\end{array}$ & $\begin{array}{l}5.08(1.57- \\
16.37)\end{array}$ & $0.006 *$ \\
\hline & $\leq 5$ years & $6(4)$ & $62(34.8)$ & 1 & 1 & 1 \\
\hline \multirow[t]{2}{*}{ Place of ART follow-up } & Hospital & $85(57.1)$ & $45(25.3)$ & $\begin{array}{l}3.93(2.46- \\
6.27)\end{array}$ & $\begin{array}{l}3.53(1.77- \\
7.04)\end{array}$ & $0.00 I^{*}$ \\
\hline & Health center & $64(42.9)$ & $133(74.7)$ & 1 & 1 & 1 \\
\hline \multirow[t]{2}{*}{ Presence of treatment support for child } & Yes & $87(58.3)$ & $22(12.4)$ & $\begin{array}{l}9.95(5.73- \\
17.29)\end{array}$ & $\begin{array}{l}3.84(1.88- \\
7.85)\end{array}$ & $0.001 *$ \\
\hline & No & $62(41.7)$ & $156(87.6)$ & 1 & 1 & 1 \\
\hline
\end{tabular}

Note: *p-value less than 0.05 .

Abbreviations: I, reference category; OR, odds ratio; AOR, adjusted odds ratio.

\section{Data Collection Tool, Procedures, and Quality Control}

Structured questionnaires were developed after reviewing relevant literature. The questionnaire was prepared in English language, translated to the local language (Amharic and sheka) and then back to English to check its consistency. Two supervisors and six data collectors were recruited and offered 2 days of training on how to collect the data and clarification of the questionnaire before the actual task was undertaken. Then data were collected by interviewer administered questions using a structured questionnaire. Secondary data were extracted from records and a data base using a checklist which was prepared based on the patient monitoring chart.

\section{Data Management and Analysis}

Filled questionnaires were checked for completeness, cleaned, coded, and entered into EPI data statistical software version 3.1 and exported to SPSS windows version 23 for further analysis. Frequencies, proportions, and summary statistics were used to describe the study population in relation to relevant variables and presented using narration and tables. The Bivariate analysis was employed to identify candidate variables for multivariable analysis. Then variables found to have $p$-values of less than 0.25 were entered into the Multivariable Logistic regression for controlling the possible effects of confounders. Finally, variables which had significant associations were identified at a $p$-value $<0.05$ and Adjusted OR with 95\% CI were determined to see the 
strength of the associations. Hosmer and Lemeshow test was used to check the fitness of the model.

\section{Results}

\section{Sociodemographic Characteristics of Caregivers and HIV-Positive Children on ART}

A total of 327 caregivers of HIV-positive children aged from 6-15 years participated in the study, yielding a $95 \%$ response rate. About three-fourths of the respondents were female and the mean age of the respondents was 36.39 years $(\mathrm{SD}= \pm 6.798)$ (Table 1).

The mean age of the children was $10.39( \pm 2.394)$. The mean duration of stay on ART was 6.7 years $( \pm 2.413)$. More than half, $192(58.7 \%)$ of the children on ART take medication with help from their caregivers. Seventy-eight (24\%) of the HIV-positive children had lost his/her family because of HIV (Table 2).

\section{Prevalence of HIV Status Disclosure to Infected Children}

The prevalence of HIV disclosure to infected children was $45.6 \%(95 \% \mathrm{CI}=41-1)$. The mean age among disclosed and non-disclosed infected children was 12.02 years $( \pm 1.769)$ and 9.03 years $( \pm 1.958)$, respectively. About 80 $(53.7 \%)$ of HIV status disclosures were made by biological family, followed by $61(40.9 \%)$ health professionals.

\section{Factors Associated with HIV-Positive Status Disclosure to Infected Children}

In bi-variable analysis 12 variables; age of caregivers, age of the child, residence, educational status of the caregivers, place of ART follow-up, presence of treatment support, history of admission, caregivers discussion with the health professionals about disclosure, caregivers knew other people who had a disclosure experience, age of the child at initiation of ART, duration on ART, and child questioning about their illness were found to be a candidate for the multivariable logistic regression model. Finally, six variables explained the final regression model. Educational status of the caregivers, caregivers discussion with health professionals about disclosure, age of the child, duration on ART, place of ART follow-up, and presence of treatment support for the child were independent predictors of HIV-positive status disclosure to infected children (Table 3).

\section{Discussion}

In this study the overall disclosure status of ART user's children was $45.6 \%(95 \% \mathrm{CI}=41-51)$. This finding was in line with studies done in Dire Dawa and Harari (49.4\%), Gondar (44\%), and West shoa (43.6\%) in Ethiopia. ${ }^{12,13,19}$ This could be because of methodological similarities and possibly because the age groups studied were similar in Gondar and west shoa studies. But, this finding is lower than a study done in Uganda (56\%) and Zimbabwe (66.9\%). ${ }^{20,21}$ The possible justification might be a difference in study population selection. A study done in Uganda includes older adolescents, which overestimate the prevalence of disclosure. This might be due to older adolescents being able to get reach information through school or media and they are perceived matured to understand. On the other hand a study done in Zimbabwe used a prospective cohort design which allows a room to follow participants. Additionally there is a sociocultural difference. However, the prevalence of this study seems higher when compared to studies done in Nigeria (33\%), Ghana (23.3\%), Tanzania (33\%), South Africa (27\%), and also studies done in Ethiopia at Hawassa $(33.3 \%)$ and Bale $(28.5 \%) .{ }^{11,14,22-25}$ The possible reason could be due to sociocultural differences and methodological differences.

In this study, caregivers of HIV-positive children with secondary education were significantly more likely to have disclosed HIV status to their children compared to those with less education. This study is consistent with a study from Gondar Ethiopia. ${ }^{13}$ This could be that those educated caregivers may get reach information on the benefit of disclosure and may have a better understanding and problem-solving skills. However, this is in contrast with a study done in South Africa. $^{26}$ Probably those educated might fear that children would inadvertently disclose their HIV status to others and thereby bring dishonor on the family despite their better understanding of the problem. On the other hand the sociocultural difference might confound the difference.

In this study, caregivers' discussions with health professionals increase the chance of disclosure. Possible justification might be caregivers who had the opportunity to discuss disclosure with healthcare providers have more information and skills to inform the HIV status of their children. This was consistent with a study conducted in Tanzania. ${ }^{27}$

The age of the child was one independent predictor of disclosure. The odds of disclosure to HIV-positive children increase as the age of the child increases. Children in the age group between 10-15 years had an increased chance of disclosure. This could be explained that, as their age 
increases their maturity would increase and there was a higher opportunity for information. Therefore they would be expected to understand the condition. This study is supported by studies conducted in Bale, Gondar, Nigeria, South Africa, Tanzania, and Zimbabwe. ${ }^{13,14,21-23,25}$

In this study children on ART for more than 5 years had a significant association to disclosure. Those children who stayed on ART for a long period of time might have a possibility to ask questions about their illness and medication they use. In addition to this, repeated follow-up may create an opportunity for caregivers to disclose. This finding was in agreement with studies conducted in Hawassa and Bale, Ethiopia. ${ }^{11,14}$

ART follow-up at hospital was significantly associated to disclosure compared to health centers. This could be explained as commonly hospitals are found in a town, where there is high chance of access to information, whereas mainly health centers are found in remote areas to increase the accessibility of service. Additionally there might be a high turnover of staff from remote areas and a high chance of a cohort of skilled professionals in hospitals. This finding is in line with a study conducted in Gondar, northern Ethiopia. $^{13}$

In this study having treatment support had an association with disclosure of HIV infection among children. This might be due to the reason that disclosure is a process which could take time. The presence of active treatment support would provide continuous guidance and facilitation to ease disclosure. This finding is in agreement with a previous study conducted in Bale, southeast Ethiopia. ${ }^{14}$

Disclosure of HIV status to infected children would have a great contribution to reduce HIV transmission in the population, improve drug adherence and enables psychosocial readiness and coping mechanism among HIVpositive children. Therefore, this would have a contribution for sustainable development goal 3 which aims to ensure healthy lives and promote well-being for all at all ages, including people living with HIV.

A limitation of this study is that sociocultural factors have been missed. A further prospective study on a large size of study participants or randomized clinical trials is needed to better understand the actual predictors of disclosure among children living with HIV.

\section{Conclusion}

This study concludes that the prevalence of HIV-positive serostatus disclosure to infected children is low. The educational status of caregivers, caregivers discussion with health professionals, age of the child, duration on ART, place of ART follow-up and treatment support for the child were significantly associated with HIV-positive status disclosure among children on ART. Therefore, health professionals should strengthen disclosure counseling for caregivers as well as children and link children to treatment support groups. The zonal health office with health centers should strengthen the quality of ART service at health centers and they should take lessons from hospitals. Finally, the Ministry of Education should work on addressing education for all and should work more to end illiteracy in Ethiopia.

\section{Abbreviations}

AIDS, acquired immunodeficiency syndrome; AOR, adjusted odds ratio; ART, antiretroviral therapy; CI, confidence interval; COR, crude odds ratio; HIV, human immunodeficiency virus; SD, standard deviation; SDG, sustainable development goal; ANECCA, African Network for the Care of Children Affected by HIV/ AIDS; WHO, World Health Organization.

\section{Data Sharing Statement}

The authors agree to provide any required data as per the guidelines of the Pediatric Health, Medicine and Therapeutics journal upon request.

\section{Ethics Approval and Consent to Participate}

The study was conducted after ethical review and clearance of the proposal by the Institutional Ethical Review Board (IRB) of Jimma University Institute of Health (JUIH) (Ref. No. IHRPGC/1034/2020) received. Permission letter was obtained from Bench sheko and west omo zone Health office department and also from the Chief executive officer and medical directors of health facilities. This study was conducted in accordance with the Declaration of Helsinki. Also, all the fundamental ethical principles including the respondents' written informed consent, risks, benefits, and comfort of the respondents were followed according to the research ethical guidelines. Each study participant provided written informed consent before joining the study. There were no unique identifiers of HIV-positive children on the checklist and all the data collected were handled confidentially and were safely disposed. 


\section{Acknowledgments}

Jimma University is acknowledged for supporting this research work. We are also grateful for the data collectors and Bench sheko and west omo zone health office department and staffs of health facilities in the area for their valuable contribution.

\section{Author Contributions}

All authors made a significant contribution to the work reported, whether that is in the conception, study design, execution, acquisition of data, analysis and interpretation, or in all these areas; took part in drafting, revising, or critically reviewing the article; gave final approval of the version to be published; have agreed on the journal to which the article has been submitted; and agree to be accountable for all aspects of the work.

\section{Funding}

The study was funded by Jimma University.

\section{Disclosure}

The authors declare that they have no competing interests.

\section{References}

1. UNAID. Fact sheet: global HIV \& AIDS statistics in 2019. 2020.

2. PEPFAR. Ethiopia Country Operational Plan (COP/ROP)-strategic direction summary. USA Washington DC. 2019.

3. Britto C, Mehta K, Thomas R, Shet A. Prevalence and correlates of HIV disclosure among children and adolescents in low- and middle-income countries systematic review. J Dev Behav Pediatr. 2016;37:496-505. doi:10.1097/DBP.0000000000000303

4. World Health Organization. Guideline on HIV Disclosure Counseling for Children Up to 12 Years of Age. Geneva, Switzerland: World Health Organization; 2011.

5. Butler AM, Williams PL, Howland LC, Storm D, Hutton N, Seage GR. Impact of disclosure of HIV infection on health-related quality of life among children and adolescents with HIV infection. Pediatrics. 2009;123:935-943. doi:10.1542/peds.2008-1290

6. Vreeman RC, Gramelspacher AM, Gisore PO, Scanlon ML, Nyandiko WM. Disclosure of HIV status to children in resource-limited settings: a systematic review. J Int AIDS Soc. 2013;16:18466. doi:10.7448/IAS.16.1.18466

7. Aderomilehin O, Hanciles-Amu A, Ozoya O. Perspectives and practice of HIV disclosure to children and adolescents by health-care providers and caregivers in sub-Saharan Africa: a systematic review. Front Public Health. 2016;4. doi:10.3389/fpubh.2016.00166

8. Doat AR, Negarandeh R, Hasanpour M. Disclosure of HIV status to children in Sub-Saharan Africa: a systematic review. Medicina. 2019;55:433. doi:10.3390/medicina55080433

9. USAID, PEPFAR, ANECCA. Handbook on counseling and psychosocial care for children and adolescents living with and affected by HIV in Africa. USA Washington DC. 2018.

10. Federal ministry of Ethiopia. National guidelines for comprehensive HIV prevention, care and treatment. Addis Ababa, Ethiopia, 2017.
11. Tadesse BT, Foster BA, Berhan Y, Tang JW. Cross Sectional Characterization of Factors Associated with Pediatric HIV Status Disclosure in Southern Ethiopia. PLoS One. 2015;10:e0132691. doi:10.1371/journal.pone.0132691

12. Mengesha MM, Dessie Y, Roba AA. Perinatally acquired HIV-positive status disclosure and associated factors in Dire Dawa and Harar, Eastern Ethiopia: a health facility-based cross-sectional study. BMJ Open. 2018;8 (8):e019554. doi:10.1136/bmjopen-2017-019554

13. Abegaz BF, Walle TA, Tilahun AD. HIV positive status disclosure and associated factor among HIV infected children in pediatric ART clinics in Gondar town public health facilities, North West Ethiopia. $J$ Infect Public Health. 2019;12:873-877. doi:10.1016/j. jiph.2019.05.018

14. Lencha B, Ameya G, Minda Z, Lamessa F, Darega J. Human immunodeficiency virus infection disclosure status to infected school aged children and associated factors in bale zone, Southeast Ethiopia: cross sectional study. BMC Pediatr. 2018;18(1):356. doi:10.1186/s12887018-1336-z

15. Montalto GJ, Sawe FK, Miruka A, et al. Diagnosis disclosure to adolescents living with HIV in rural Kenya improves antiretroviral therapy adherence and immunologic outcomes: a retrospective cohort study. PLoS One. 2017;12(10):e0183180. doi:10.1371/journal. pone. 0183180

16. Federal ministry of Ethiopia. National consolidated guidelines for comprehensive HIV prevention, care and treatment, Addis Ababa, Ethiopia. 2018.

17. Sariah A, Rugemalila J, Somba M, et al. "Experiences with disclosure of HIV-positive status to the infected child": perspectives of healthcare providers in Dar es Salaam, Tanzania. BMC Public Health. 2016;16. doi:10.1186/s12889-016-3749-7

18. Abdissa HG, Lemu YK, Nigussie DT. amd Nigussie DT: HIV preventive behavior and associated factors among mining workers in Sali traditional gold mining site bench maji zone, Southwest Ethiopia: a cross sectional study. BMC Public Health. 2014;14:1003. doi:10.1186/1471-2458-14-1003

19. Shallo SA, Tassew M. HIV positive status disclosure and its associated factors among children on antiretroviral therapy in West Shoa Zone, Western Ethiopia 2019: a mixed method cross-sectional study. $J$ Multidiscip Healthc. 2020;13:507-517. doi:10.2147/JMDH. S258851

20. Ekirapa-Kiracho E, Namasopo-Oleja S, Bagenda D:. Factors affecting disclosure of serostatus to children attending Jinja Hospital Paediatric HIV clinic, Uganda. Afr Health Sci. 2015;15(2):344-351. doi:10.4314/ahs.v15i2.6

21. Finnegan A, Langhaug L, Schenk K, et al. The prevalence and process of pediatric HIV disclosure: a population-based prospective cohort study in Zimbabwe. PLoS One. 2019;14(5):e0215659. doi:10.1371/journal.pone.0215659

22. Ubesie AC, Iloh KK, Emodi IJ, et al. HIV status disclosure rate and reasons for non-disclosure among infected children and adolescents in Enugu, southeast Nigeria. $J$ Soc Aspects HIV/AIDS. 2016;13:136-141. doi:10.1080/17290376.2016.1226942

23. Madiba S, Mokgatle M. Fear of stigma, beliefs, and knowledge about HIV are barriers to early access to HIV testing and disclosure for perinatally infected children and adolescents in rural communities in South Africa. South African Fam Pract. 2017;59(5):175-181. doi:10.1080/20786190.2017.1329489

24. Hayfron-Benjamin A, Obiri-Yeboah D, Ayisi-Addo S, Siakwa PM, Mupepi S. HIV diagnosis disclosure to infected children and adolescents; challenges of family caregivers in the Central Region of Ghana. BMC Pediatr. 2018;18. doi:10.1186/s12887018-1330-5 
25. Bulali RE, Kibusi SM, Mpondo BCT. Factors associated with HIV status disclosure and its effect on treatment adherence and quality of life among children 6-17 years on antiretroviral therapy in Southern Highlands Zone, Tanzania: unmatched case control study. Int J Pediatr. 2018;2018:1-10. doi:10.1155/2018/8058291

26. Naidoo GD, McKerrow NH. Current practices around HIV disclosure to children on highly active antiretroviral therapy. South African J Child Health. 2015;9(3):85. doi:10.7196/SAJCH.7957
27. Livin Peter Mumburi LP, Hamel BC, Philemon RN, Kapanda GN, Msuya LJ. Factors associated with HIV-status disclosure to HIV-infected children receiving care at Kilimanjaro Christian Medical Centre in Moshi, Tanzania. Pan African Med J. 2014.

\section{Publish your work in this journal}

Pediatric Health, Medicine and Therapeutics is an international, peerreviewed, open access journal publishing original research, reports, editorials, reviews and commentaries. All aspects of health maintenance, preventative measures and disease treatment interventions are addressed within the journal. Practitioners from all disciplines are invited to submit their work as well as healthcare researchers and patient support groups. The manuscript management system is completely online and includes a very quick and fair peer-review system. Visit http://www.dovepress.com/testimonials.php to read real quotes from published authors.

Submit your manuscript here: http://www.dovepress.com/pediatric-health-medicine-and-therapeutics-journal 